\title{
Integrating Topics of Renewable Energy into the Science Curricula of the Middle Stage in Saudi Arabia
}

\author{
Nisreen H. Subahi (Corresponding author) \\ Faculty of Education, University of Jeddah, Jeddah, Saudi Arabia \\ E-mail: d.alsubahi@hotmail.com
}

Received: March 17, 2020 Accepted: April 16, 2020 Published: April 26, 2020

doi:10.5296/jei.v6i1.16710 URL: https://doi.org/10.5296/jei.v6i1.16710

\begin{abstract}
The present study aims to determine how far topics of renewable energy are included in the science curricula of the middle stage in Saudi Arabia. Thus, the study adopts the analytical descriptive approach. The sample comprised the science curricula of the second middle year (two semesters). The author developed and applied a form, whose validity and reliability had been verified, covering a list of topics about renewable energy to determine the significance of integrating those topics into the science curricula of the middle stage. The list included six major topics with sub-items related to renewable energy. Moreover, a tool was utilized to analyze the sample curricula to explore how far they tackled topics of renewable energy. The results revealed that the science curricula of the second middle year did not adequately cover renewable energy (only 16.62\%). Accordingly, the study recommended reviewing the science curricula of the middle stage to ensure the integration of renewable energy and conducting further studies to explore how far renewable energy is integrated into the science curricula of different stages.
\end{abstract}

Keywords: Topics of renewable energy, Science curricula, Content analysis, Middle stage

\section{Introduction}

Energy is the basis of any human growth and development. Current global resources of energy are traditional and unsustainable. They pollute the environment and cause harmful emissions. They also do not maintain sustainable development. On the contrary, sustainable energy aims at protecting the environment and ensuring the optimal use and equal distribution of resources for present and subsequent generations.

Community progress relates to developing human energy and exploring extraordinary mental energy because they can overcome different challenges and generate innovative solutions (Alkhafaf, 2016). Additionally, the progress of nations is measured by the mental growth of 
the people and the ability to positively and effectively invest those skills and capacities in a way that copes with the present era (Altaleby, 2002).

Accordingly, all countries seek sustainable developmental solutions for the environment regardless of the black economy causing environmental pollution. There are international interest and encouragement to use and invest in clean energy due to its effects on supporting eco-friendly economic growth. All countries seek to convert to a green economy by encouraging renewable energy investments as an optimal and first option (Shawaheen, 2009). Since the last decade of the $20^{\text {th }}$ century, a modern educational trend has emerged in the US where educators called for necessarily adopting eco-friendly alternative energy known as renewable energy.

Renewable energy is one of the modern topics that have earned great global attention as a core of community development. Therefore, the world needs more sustainable and less polluting energy resources, such as solar, wind, hydropower, geothermal, and fuel cell energies. Renewable energy is the optimal source of fossil energy resources, including oil, natural gas, and coal, which are now being rapidly depleted. In addition, nuclear energy as an alternative source of fossil energy is a true source of environmental pollution (AlHilaly, 2015).

The 2002 World Summit of Economic and Social Commission for Western Asia recommended integrating all types and concepts of the topics of renewable energy into educational programs at different educational stages. It also recommended delivering various related training programs in cooperation with international organizations. The International Conference on Renewable Energy at the College of Sciences, University of Hail (2019) stressed that KSA has a large quantity and remarkable potentials for the success of natural resources of renewable energy, such as solar energy and wind energy, in terms of inputs and geographical locations. According to Sayigh (2000), the World Renewablle Energy Congress VI tackled the significance of raising awareness and disseminating the culture of renewable energy in the $21^{\text {st }}$ century.

Many foreign and Arabic studies, e.g., Ahmad, Abdelkarim, and Muhammad (2017), Ahmad and Muhammad (2012), Ahmad and Shanif (2014), Almohga (2018), and Alsamra'y (2011), recommend the interest and development of the topics of renewable energy among learners via curricula and adopting various methods to raise awareness. Shedding light on science curricula reveals that they have a special nature because of their educational content, which is various, innovative and relevant to the environment outside schools. In addition, they are easily connected to community activities (Kolsto, 2008). Science curricula should integrate traditional concepts with recent advancements. They have to be renovated for their elements, topics, thinking styles, concepts, objectives, and attitudes to develop the educational process. It is very significant to integrate topics of renewable energy in science curricula at all educational stages due to their role in enriching knowledge and motivating learners to learn. These concepts are easily employed in real-life situations and giving learners the chance to explore and solve potential community problems (Almohga, 2018).

Thus, the Saudi Ministry of Education has developed comprehensive science curricula in the 


\section{Macrothink}

project of Saudi Mathematics and Natural Science Curriculum Development at Public Schools approved by the Council of Ministers in November 2004. The project is based on some major principles, such as relating public education to authentic contexts and developing students' skills and capacities to make decisions, think, investigate, and present planned initiatives (Ministry of Education, 2010). The author is motivated to conduct the present study to identify topics of renewable energy and their integration in the science curricula of the middle stage.

\subsection{Statement of the Problem}

The world has encountered multiple challenges that reveal problems in the depletion of natural resources, fossil energy, and pollution. Therefore, renewable energy is a major topic of science, which includes several scientific concepts and applications related to real-life individually or collectively. Curricula play a significant role in offering the topics of renewable energy to learners to raise awareness, provide them with methods of handling them, and take proper decisions to overcome relevant problems (Almohga, 2018).

The results of the relevant studies have shown the significance of developing the Saudi science curricula to cope up with the global advancements and to activate learners' role to feel related to the community. The author conducted a pilot study to explore and employ the awareness of middle-stage science teachers of the topics of renewable energy in teaching science. The results showed low awareness among teachers rated (58\%). Some teachers argued that the content of the curricula does not support raising awareness. Therefore, the present study aims at analyzing the content of the science curricula of the middle stage to find out how far they include topics about renewable energy.

The problem of the study is defined in the following major question:

How far does the content of the Saudi science curricula of the middle stage integrate topics about renewable energy?

It is divided into the following minor questions:

(1) What topics of renewable energy are integrated into the content of the science curricula of the middle stage in KSA?

(2) To what extent do the science curricula of the middle stage integrate topics of renewable energy?

\subsection{Objectives}

The present study aims at:

(1) Identifying topics of renewable energy in the science curricula of the middle stage in KSA.

(2) Exploring the integration of the topics of renewable energy into the science curricula of the middle stage. 


\section{Mll Macrothink}

\subsection{Significance}

It is a significant study because,

(1) It may draw the attention of the concerned bodies to develop science curricula of the middle stage to include topics of renewable energy to cope with modern scientific trends.

(2) It explores the position of science curricula of the middle stage as for integrating topics of renewable energy and standards of teaching them.

(3) It provides an important theoretical framework of a modern trend in teaching science, i.e. topics of renewable energy.

(4) It concludes results and recommendations that raise awareness of topics of renewable energy in science curricula and the requirements of presenting them effectively.

(5) The results can be a starting point for more research and studies on the topics of renewable energy.

\subsection{Limits}

\subsubsection{Temporal Limits}

The present study was conducted in the first semester of the academic year 2019/2020 $(1440 / 1441 \mathrm{H})$.

\subsubsection{Spatial Limits}

The study was conducted in KSA.

\subsubsection{Topic Limits}

They include six topics of renewable energy of the science curricula of the second middle year (two semesters) in 2019/2020, namely (renewable energy and resources, properties and advantages of renewable energy, uses of renewable energy, obstacles to employing renewable energy, potentials of renewable energy in KSA, and state efforts to employ renewable energy).

\subsection{Definition of Terms}

\subsubsection{Renewable Energy}

It is a science that studies non-depletable energy resources, e.g., oil, and their harmful environmental effects, such as solar, wind and hydropower energies (Shawaheen, 2009). The Energy and Fuel Research Center (2009) defines renewable energy as a science that studies immature natural resources. They are naturally available either they are limited or not but they are permanently renewable and environmentally clean. Moreover, they do not cause pollution. As a science, renewable energy studies global energy resulting from biomass $(11 \%)$, hydropower (3\%), as well as wind and geothermal energies (Verney, 2011, p. 8). 


\subsubsection{Topics of Renewable Energy}

The author procedurally defines them as the information, facts, and ideas relevant to renewable energy and included in the list of renewable energy topics prepared to suit the objectives of the present study.

\subsubsection{Science Curricula}

Ali (2012, p. 13) defines them as part of the educational program that covers a set of educational topics to be delivered to students throughout one semester or more. It has a complete specification determining the teacher, target students, and learning objectives on the course of study. In addition, a curriculum includes the educational requirements and assessment methods to evaluate the achievement of objectives.

The author defines them procedurally as the content of a science course delivered to second-year middle stage students issued by the Ministry of Education in the academic year 2019/2020.

\subsubsection{Content Analysis}

It is a research method utilized to analyze book contents by analyzing the idea and elements and providing a qualitative description to identify the characteristics in a systematic, not a quantitative manner based on personal impressions (Muhammad \& Abdul Azeem, 2012).

The author procedurally defines it as the quantitative description of topics of renewable energy included in the science curriculum of the second middle year.

\section{Theoretical Framework}

\subsection{Renewable Energy}

Renewable energy is a modern scientific innovation. The term refers to energy resources that are renewable and permanent. It also refers to the energy generated from untraditional natural sources that are permanent and inexhaustible. Those sources are converted by modern technologies from a natural form, including wind, water, and biomass, to another usable energy. That kind of energy provides a permanent stock provided that consumption rates do not exceed the natural rate of renewal (Mahrous, 1982, p. 175).

Accordingly, alternative and less harmful resources of energy can be provided by harnessing the energy of the sun, biomass, and fuel cells (Ali, 2007). The man discovered, harnessed, and employed the resources of renewable energy in various ways that evolved according to life patterns and needs. For example, solar power is used to dry food and wind power is used to sail ships and to operate windmills to grind grains (Alkhayat, 2006).

\subsection{The Need to Integrate Topics of Renewable Energy into Curricula}

Many challenges and problems have raised concerning the depletion of natural and fossil energy and pollution, causing danger to the environment. Thus, people look for new alternative energy resources to keep environmental balance and to keep moving forward. Those resources should be clean, renewable, and untraditional. Educational institutions pay 
attention to that human need because the relationship between science and technology is an integrative one aiming at keeping pace with advancements and providing knowledge balance for learners who are the core of any social texture (Almohga, 2018). The Eighth Development Plan in Saudi Arabia has assured the necessity of reviewing curricula to include topics of environmental awareness from early elementary years. It has also highlighted the coordination with the Ministries of Culture and Media regarding the best ways of developing educational and awareness programs about the environment and disseminating global, regional, and local issues (Ministry of Economy and Planning, 2015). Educational curricula play an active role in providing learners with the topics of renewable energy to raise awareness and to know confrontation methods.

Renewable energy is a significant topic to be delivered through science curricula. It contains authentic scientific concepts and applications relevant to real life. Thus, learners can have a point of view about instilling citizenship values and making proper decisions to overcome issues related to renewable energy.

\subsection{Renewable Energy and the Saudi Vision 2030}

On April 25 $5^{\text {th }}$, 2015, the Saudi Council of Ministers approved a new national charter is known as (Saudi Vision 2030). The Saudi Council of Economic and Development Affairs sets the mechanisms and follows up ministries and target entities through key performance indicators in implementing the Vision's programs and mechanisms. Vision 2030 is a plan for joining and organizing government and private work to achieve progress and prosperity for the Kingdom to be a global pioneering model in all fields. It depends on three themes: building a vibrant society, a thriving economy, and an ambitious nation (Saudi Vision 2030, 2016). The Saudi Vision 2030 pays much attention to the economy and education in KSA.

The Vision sets out a plan to grow and diversify the economy to move Saudi Arabia from twentieth place up to the best fifteen economies all over the world. Therefore, a ministerial change has been taken where the Ministry of Energy, Industry and Mineral Resources has replaced the Ministry of Petroleum and Mineral Resources to add more tasks and duties.

To build the institutional capacity and capabilities needed to achieve the ambitious goals of the Saudi Vision 2030, the National Transformation Program 2020 was launched across 24 government bodies operating in the economic and development sectors in the first year, including the Ministry of Education. The Council of Economic and Development Affairs established 13 Vision Realization Programs such as the National Transformation Program 2020, the Government Restructuring Program, and the Project Management Program. All programs and indicators are designed to achieve compatibility with sustainable development goals (Saudi Vision 2030, 2016).

\subsection{The National Renewable Energy Program}

Therefore, it is very crucial to adopt topics of renewable energy to highlight its significant role in different fields to reduce the consequences of climate change and meet local energy needs, which contribute to enhancing energy security. The National Renewable Energy Program was launched to be a strategic initiative in the reign of Salman bin Abdul Aziz Al 


\section{$\triangle$ Macrothink}

Saud. It is cascaded from the Saudi Vision 2030 and the National Transformation Program 2020. It aims to produce $5.9 \mathrm{GW}$ of renewable energy by 2023 and an interim goal of producing $45.3 \mathrm{GW}$ by 2020 .

The Saudi Vision 2030 highlights some obstacles to the spread of renewable energy projects. Thus, it is necessary to provide economic, societal, and educational support to enhance renewable energy opportunities aiming at raising awareness of its significance and building marketing capacities.

\section{Literature Review}

Many authors addressed renewable energy from different perspectives. For example, Almohga (2018) explored the impact of employing Web Quest instruction on students' attitudes towards issues of renewable energy. The study adopted the quasi-experimental approach. It covered and distributed a sample of 72 female fifth-graders at a school in Al-Qadisiyah into two groups: Control and experimental. It utilized a scale of attitudes towards renewable energy issues. It concluded the effectiveness of employing Web Quest instruction in developing the sample's attitudes towards issues of renewable energy.

Ahmad et al. (2017) examined the impact of an educational program based on the concepts of renewable energy and nanotechnology on technological enlightenment among students of the Chemistry Department, College of Education for Pure Sciences. The authors adopted the quasi-experimental approach. The study was applied to a sample of third-year-students, Chemistry Department distributed into two equal groups (24 students each). The authors developed a list of concepts of renewable energy and nanotechnology, the content of the proposed program, and the scale of technological enlightenment. The results indicated the effectiveness of the proposed program in improving technological enlightenment among the participants.

Sulaiman, Fardoun, and Nour (2014) investigated the significance of providing a course in renewable energy based on the investigation method for engineering freshmen. The study was conducted on three groups: A group of graduates and two groups of undergraduates, one of them studied renewable energy and the other did not. The authors created a questionnaire of some items related to renewable energy and sustainable development. The results revealed that most of the participants believed that activities related to renewable energy should be integrated into curricula as a major income resource by 2020 .

Ahmad and Shanif (2014) explored the impact of employing probing questions on improving the attitudes of fourth-high graders (science section) towards the issues of renewable energy. The population covered all female students of the fourth-high grade at Alrabab High School in Al-Qadisiyah. The authors selected and distributed a random sample of (73) into a control group and an experimental group. They developed a 44-item scale of the attitudes towards issues of renewable energy of three domains (the cognitive, affective, and tendency). After verifying the scale's validity and reliability, it was applied to the control and experimental groups. The results revealed a statistically significant difference in the mean score of attitudes of the groups in favor of the experimental group. 


\section{$\triangle$ Macrothink}

Ahmad and Muhammad (2012) tackled the concepts of renewable energy among students of Colleges of Education and Science and the relation to environmental awareness. The authors randomly selected a sample of 170 students in the Department of Chemistry in both colleges in Baghdad. They adopted two tools: A 45-question test about acquiring concepts of renewable energy measuring the definition, example, and application of concepts and a 65 -item scale of environmental awareness. The results indicated that gaining concepts of renewable energy among students of Colleges of Education and Science rated $96.44 \%$ and $60.44 \%$, respectively. The study recommended integrating concepts of renewable energy in chemistry curricula and considering modern advancements.

Alsamra'y (2011) explored how far students of the Colleges of Education and Science gained the concepts of renewable energy and relationship to environmental awareness. She adopted the descriptive survey method and selected a sample of 170 students at Baghdad University. She developed a test of the concepts of renewable energy and a scale of environmental awareness. The results revealed that the level of gaining concepts of renewable energy was low and rated (44.96\%) and (60.44\%) among the students of the Colleges of Education and Science, respectively. The study recommended integrating concepts of renewable energy in chemistry curricula and considering modern advancements. The present study utilized the results, tools, and references to the literature.

\section{Methodology}

\subsection{Method}

The present study adopted the analytical descriptive approach based on content analysis. Analyzing the contents of a book means analyzing ideas and elements as well as providing a qualitative description to identify its characteristics in an organized scientific way (Muhammad \& Abdul Azeem, 2012). Therefore, the study adopts this method to explore how far topics of renewable energy have been integrated into the science curricula of the second year middle stage in KSA. The idea module is the unit of analysis. The study divides ideas into two types: explicit ideas that are clearly and directly stated in a simple or complex clear sentence and implicit ideas that are implied in an indirect sentence or activity.

\subsection{Population}

It includes all the science curricula for the middle stage (two semesters) issued by the Ministry of Education in the Kingdom of Saudi Arabia in the academic year 2019/2020.

\subsection{Sampling}

It is the science curricula of the second middle year (two semesters) issued by the Ministry of Education in the Kingdom of Saudi Arabia, including its objectives, activities, illustrations, and evaluation.

\section{Tool}

The author developed a list of topics of renewable energy to explore how far topics of renewable energy are included in the science curricula of the second middle year in the 


\section{Macrothink}

Kingdom of Saudi Arabia. Then, a tool for content analysis was derived from the previous tool. The tool was designed in terms of Saudi Vision 2030, the General Authority for Statistics in KSA (renewable energy indicators in KSA), and the results of the literature. The tool included 6 major domains and 30 items.

\subsection{Design}

To design the tool, the author reviewed some previous analysis tools for renewable energy. Hence, the present tool included 6 major domains and 30 items, as shown in Table 1.

Table 1. Topics of renewable energy to be integrated into the science curricula of the middle stage

\begin{tabular}{|l|l|l|}
\hline Domain & Definition & Items \\
\hline Renewable energy and resources & $\begin{array}{l}\text { The definition of alternative energy, types, and } \\
\text { definition of each type }\end{array}$ & $1-6$ \\
\hline Properties and advantages of renewable energy & $\begin{array}{l}\text { The prominent characteristics of all types of } \\
\text { alternative energy }\end{array}$ & $7-10$ \\
\hline Uses of renewable energy & The different fields of employing alternative energy & $11-14$ \\
\hline Obstacles to employing renewable energy & $\begin{array}{l}\text { The obstacles to employing each type of } \\
\text { renewable energy }\end{array}$ & $15-18$ \\
\hline Potentials of renewable energy in KSA & The potentials of renewable energy in KSA & $19-23$ \\
\hline The state efforts to employ renewable energy & $\begin{array}{l}\text { The achievements and efforts exerted by the } \\
\text { government in the field of renewable energy }\end{array}$ & $24-30$ \\
\hline
\end{tabular}

Then, the author calculated the coefficient correlations between the score of each domain and the total score of the questionnaire, as shown in Table 2.

Table 2. Coefficient correlations between the scores of each domain and the total score of the questionnaire

\begin{tabular}{|l|l|}
\hline Domain & Coefficient correlation \\
\hline Renewable energy and resources & $* * 0.949$ \\
\hline Properties and advantages of renewable energy & $* * 0.967$ \\
\hline Uses of renewable energy & $* * 0.818$ \\
\hline Obstacles to employing renewable energy & $* * 0.922$ \\
\hline Potentials of renewable energy in KSA & $* * 0.960$ \\
\hline The state efforts to employ renewable energy & $* * 0.864$ \\
\hline
\end{tabular}

Note. ${ }^{* *}$ statistically significant at the level of $(0.01)$. 


\section{Macrothink Minstitutem}

Table 2 indicates high values of the coefficient correlations of the domains and the total score of the tool ranging from 0.818 to 0.967 . All the values were statistically significant at the level of 0.01 , indicating high construct validity.

Validity: After designing the tool, it was reviewed by some specialists to ensure that the topics and items fit the study objectives and that they all are well-worded. The reviewers made precious comments to make the tool more proper. The author reviewed the tool in accordance. Thus, the tool achieved face validity and became ready in its final draft (Appendix A).

Reliability: The author did a content analysis of the science curricula of the second middle year (two semesters). Then, she reanalyzed them two weeks later. To verify the analysis reliability, the author calculated the coefficients of agreement between the two analyses using Cooper formula, as follows:

$$
\text { Agreement coefficient }=\frac{\text { Number of agreement times }}{\text { Number of disagreement times }+ \text { number of agreement times }} \times 100
$$

After doing the analysis, the author calculated the coefficient of agreement between the two analyses, which were ( 8 and 9 ) indicating, a proper reliability factor of the study. Therefore, the tool contained 30 items distributed to 6 domains.

\subsection{Procedures}

The author did the following steps:

(1) Setting the study objectives, questions, and methods.

(2) Selecting the curricula to be analyzed, i.e. the science curricula of the second middle year (two semesters) in KSA.

(3) Developing an analysis card of the topics of renewable energy in the science curricula of the second middle year (two semesters) by reviewing the literature.

(4) Verifying the tool validity and analysis reliability.

(5) Covering all curricula in terms of objectives, activities, illustrations, and evaluation.

(6) Accurately reading the curricula texts to identify frequencies according to the tool of analysis.

(7) Recording frequencies of each topic according to the times of appearing in the content of each chapter in the curricula.

(8) Inserting the results of the analysis in a table

(9) Applying proper statistics to get results.

(10) Making recommendations and suggestions.

\section{Results}

The major question was answered by applying the tool of analyzing the curricula. To answer 


\section{Macrothink $\Lambda$ Institutem"}

the first minor question, the author created a list of the topics of renewable energy by reviewing the relevant literature. Then, she verified the validity and reliability of the list that comprised 6 major topics of renewable energy and 30 items (Table 1).

To answer the second question, the author calculated frequencies and percentages of integrating the topics of renewable energy into curricula. The results are shown in Table 3.

Table 3. Integrating the topics of renewable energy in curricula

\begin{tabular}{|c|c|c|c|}
\hline No. & Item & Frequency & Percentage \\
\hline \multicolumn{4}{|c|}{ I. Renewable energy and resources } \\
\hline 1 & Definition of renewable energy & 1 & $1.4 \%$ \\
\hline 2 & Solar energy & 5 & $2.06 \%$ \\
\hline 3 & Hydroelectric energy & 4 & $1.6 \%$ \\
\hline 4 & Wind energy & 6 & $2.4 \%$ \\
\hline 5 & Geothermal energy & 4 & $1.6 \%$ \\
\hline 6 & Hydrogen energy & 0 & 0 \\
\hline \multicolumn{2}{|c|}{ Total } & 20 & $8.07 \%$ \\
\hline \multicolumn{4}{|c|}{ II. Properties and advantages of renewable energy } \\
\hline 7 & Non-polluting resources & 1 & $0.82 \%$ \\
\hline 8 & Local resources & 0 & 0 \\
\hline 9 & Permanent resources & 2 & $0.82 \%$ \\
\hline 10 & Usable by simple technologies & 0 & 0 \\
\hline \multicolumn{2}{|c|}{ Total } & 4 & $1.64 \%$ \\
\hline \multicolumn{4}{|c|}{ III. Uses of renewable energy } \\
\hline 11 & Military uses & 0 & 0 \\
\hline 12 & Domestic uses & 6 & $2.4 \%$ \\
\hline 13 & Agricultural uses & 0 & 0 \\
\hline 14 & Industrial uses & 2 & $0.82 \%$ \\
\hline \multicolumn{2}{|c|}{ Total } & 8 & $3.22 \%$ \\
\hline \multicolumn{4}{|c|}{ IV. Obstacles to employing renewable energy } \\
\hline 15 & Technological obstacles & 0 & 0 \\
\hline 16 & Financial and economic obstacles & 1 & $0.41 \%$ \\
\hline 17 & Environmental and climate obstacles & 2 & $0.82 \%$ \\
\hline 18 & Awareness obstacles & 0 & 0 \\
\hline \multicolumn{2}{|c|}{ Total } & 3 & $1.23 \%$ \\
\hline
\end{tabular}




\begin{tabular}{|l|l|l|l|}
\hline \multicolumn{2}{|l|}{ V. Potentials of renewable energy in KSA } & 0 & 0 \\
\hline 19 & High solar radiation & 0 & 0 \\
\hline 20 & Huge desert areas & 0 & 0 \\
\hline 21 & Water bodies & 0 & 0 \\
\hline 22 & Speedy wind & 0 & 0 \\
\hline 23 & Valley slopes & $\mathbf{0}$ & $\mathbf{0}$ \\
\hline Total & & \multicolumn{2}{|l|}{} \\
\hline VI. The state efforts to employ renewable energy & 1 & $0.82 \%$ \\
\hline 24 & King Abdulaziz City for Science and Technology & 1 & $0.82 \%$ \\
\hline 25 & The Solar Village in Al-'Uyaynah & $0.82 \%$ \\
\hline 26 & King Abdullah City for Atomic and Renewable Energy & 1 & 0 \\
\hline 27 & National Development Strategy and Saudi Vision 2030 & 0 & 0 \\
\hline 28 & The Renewable Energy Project Development Office & 0 & 0 \\
\hline 29 & Sakaka solar project & 0 & 0 \\
\hline 30 & Dumat Al Jandal Wind Farm & 0 & $\mathbf{2 . 4 6 \%}$ \\
\hline Total & & $\mathbf{3}$ & \\
\hline
\end{tabular}

Table 3 highlights how far the science curricula of the second middle year handle topics of renewable energy.

The results show that the topics of the "renewable energy and resources" domain occurred 20 times $(8.07 \%)$. While wind energy was ranked first (6 times, $2.4 \%)$, solar energy was ranked second (5 times, 2.06\%). Hydroelectric and geothermal energies were ranked third and rated 4 times (1.6\%). The concept of renewable energy was ranked fourth and appeared once $(1.4 \%)$, but hydrogen energy did not appear.

The domain of "properties and advantages of renewable energy" was rated low (1.64\%) with 4 times. "Non-polluting resources and local resources" were ranked first and occurred twice $(0.82 \%)$. The other items were not handled at all $(0 \%)$.

The domain of "uses of renewable energy" occurred 8 times (3.22\%). While "domestic uses" item was ranked first (6 times, 2.4\%), "industrial uses" was ranked second (2 times, .82\%). However, military and agricultural uses were not handled.

The domain of "obstacles to employing renewable energy" were rated very low $(1.23 \%)(3$ times). The "environmental and climate obstacles" item was ranked first (twice, .082\%). The "financial and economic obstacles" item was ranked second (once, 0.41\%). However, technological obstacles and awareness obstacles were not handled at all (0\%).

The domain of "potentials of renewable energy in KSA" was not included in the curricula. In other words, the curricula are short in handling the topics of that domain. 


\section{Macrothink}

The domain of "the state efforts to employ renewable energy" was rated very low. It appeared (3 times) and rated (2.46\%). The items of "King Abdulaziz City for Science and Technology, the Solar Village in Al-'Uyaynah, and King Abdullah City for Atomic and Renewable Energy" appeared once and rated $(0.82 \%)$. The other topics were not addressed.

\section{Discussion}

Table 4 summarizes the results, as follows:

Table 4. How far science curricula of the second year middle stage include topics of renewable energy

\begin{tabular}{|l|l|l|l|}
\hline No & Topic & Frequency & Percentage \\
\hline 1 & Renewable energy and resources & 20 & $8.07 \%$ \\
\hline 2 & Properties and advantages of renewable energy & 4 & $1.64 \%$ \\
\hline 3 & Uses of renewable energy & 8 & $3.22 \%$ \\
\hline 4 & Obstacles to employing renewable energy & 3 & $2.64 \%$ \\
\hline 5 & Potentials of renewable energy in KSA & 0 & $0 \%$ \\
\hline 6 & The state efforts to employ renewable energy & 3 & $2.46 \%$ \\
\hline Total & & $\mathbf{3 8}$ & $\mathbf{1 6 . 6 2 \%}$ \\
\hline
\end{tabular}

Table 4 indicates very low rates of integrating topics of renewable energy into the curricula (38 times, 16.62\%). While "renewable energy and resources" domain was ranked first (20 times, 8.07\%), "uses of renewable energy" was ranked second ( 8 times, 3.22\%), and "properties and advantages of renewable energy" was ranked third (4 times, 1.64\%). "The state efforts to employ renewable energy" and "the obstacles to employing renewable energy" were ranked fourth (3 times, 2.64\%). The "potentials of renewable energy in KSA" was never tackled.

Accordingly, results refer to deficiencies of paying adequate attention to topics of renewable energy in the science curricula of the second middle year in KSA. Moreover, the topics are not addressed similarly. Some topics were covered at low rates, while others were completely missed. However, the literature has highlighted the significance of integrating those topics into science curricula. The results agree with the findings of Ahmad et al. (2017), Ahmad and Muhammad (2012), Ahmad and Shanif (2014), and Almohga (2018).

\section{Recommendations}

Curriculum designers should be guided to integrate topics of renewable energy into science curricula in all educational levels to reflect the state's attention to renewable energy. These topics are crucial for enriching knowledge among learners and motivating them to learn and use the topics easily in real-life situations. Topics of renewable energy should be gradually 


\section{Macrothink $\Lambda$ Institute"m}

integrated into science curricula according to the educational stage and learners' characteristics and capabilities. Introductory seminars and workshops must be delivered for teachers to raise their awareness of topics of renewable energy and linking them to teaching and designing curricula.

\section{Further Studies}

Analyzing science curricula of the first and third middle years in KSA in terms of topics of renewable energy and conducting a study on the awareness of students at the Colleges of Science of topics of renewable energy, as well as conducting further studies to analyze the integration of topics of renewable energy into the science curricula of other educational levels.

\section{References}

Ahmad, B., Abdelkarim, E., \& Muhammad, A. (2017). Impact of an educational program based on concepts of renewable energy and nanotechnology on technological enlightenment among students of the Chemistry Department. Journal of Educational and Psychological Researches, 55, 175-192.

Ahmad, B., \& Muhammad, A. (2012). Concepts of renewable energy and relationship to environmental awareness among the students of the Colleges of Education and Science. Arab Studies in Education and Psychology, 1(28), 105-126.

Ahmad, A., \& Shanif, M. (2014). Impact of employing probing questions on improving attitudes towards renewable energy among the students of the fourth high grade. Kufa Studies Journal, 32, 187-198.

Alhilaly, J. (2015). Renewable energy: Advantages, significance, uses, and obstacles. University of Dongola, 14, 242-275.

Ali, M. (2007). Education practice and teaching science (2nd ed.). Amman: Dar Almassira.

Alkhafaf, E. (2016). Intelligent behaviors-habits of mind caused by productive actions. Amman: Dar Aleasar Alealmy.

Alkhayat, M. (2007). The technology of wind energy. Arab Electricity Journal, 91, 1-8.

Almohga, N. (2018). Impact of Web Quest instruction on the student attitudes to issues of renewable energy. Journal of Basic Education for Educational and Human Sciences, 38, 1277-1289.

Alsamra'y, A. (2011). Concepts of renewable energy and relationship to environmental awareness among students of the Colleges of Education and Science (M.A. thesis, College of Education for Pure Sciences, Baghdad University).

Altaleby, N. (2002). The impact of using Jordon's model in developing creative abilities in a design course (M.A. thesis, University of Diyala, Baghdad, Iraq).

Energy and Fuel Research Center. (2009). A future vision of renewable energy in Iraq. 
Baghdad: University of Technology.

Kolsto, S. (2008). Science education for democratic citizenship through the use of the history of science. Science \& Education, 17(8), 977-997.

Mahrous, M. (1982). Introduction to economies of resources. Cairo: Egyptian Universities Press.

Ministry of Education. (2010). The project of Saudi Mathematics and Natural Science Curriculum Development at public schools. Riyadh: Ministry of Education.

Ministry of Economy and Planning. (2015). Achievement of Development Plans: Facts and Number (Vol. 31). Riyadh, Saudi Arabia.

Muhammad, W., \& Abdul Azeem, R. (2012). Content analysis in humanities. Amman: Dar Almassira.

Saudi Vision 2030. (2016). Saudi Vision 2030. Retrieved February 5, 2020, from http://vision2030.gov.sa

Sayigh, A. (2000). Renewables: The energy for the $21^{\text {st }}$ century. Oxford: Pergamon.

Shawaheen, K. (2009). Geology and environment for amateurs. Amman: Dar Almassira.

Sulaiman, A., Fardoun, A., \& Nour, M. (2014). Renewable energy education for engineering freshman students. Asian Journal of Education and E-Learning, 2(3), 173-184.

The University of Hail. (2019). The international conference on renewable energy. KSA: University of Hail.

Verney, J. (2011). Renewable energies. Abu Dhabi: Abu Dhabi Culture \& Heritage.

\section{Appendix A.}

Tool of analyzing the science curricula of the middle second year

\begin{tabular}{|c|c|c|c|c|}
\hline \multirow{3}{*}{ No } & \multirow{3}{*}{ Topics of renewable energy } & \multicolumn{3}{|c|}{$\begin{array}{l}\text { How far topics of renewable energy } \\
\text { are integrated into science curricula }\end{array}$} \\
\hline & & \multicolumn{2}{|c|}{ Yes } & \multirow{2}{*}{ No } \\
\hline & & Frequency & Percentage & \\
\hline \multicolumn{5}{|c|}{ I. Renewable energy and resources } \\
\hline 1 & Definition of alternative energy & & & \\
\hline 2 & Solar energy & & & \\
\hline 3 & Hydroelectric energy & & & \\
\hline 4 & Wind energy & & & \\
\hline 5 & Geothermal energy & & & \\
\hline 6 & Hydrogen energy & & & \\
\hline
\end{tabular}




\section{Macrothink}

\begin{tabular}{|l|l|l|l|l|}
\hline \multicolumn{2}{|l|}{ II. Properties and advantages of renewable energy } & & & \\
\hline 7 & Non-polluting resources & & & \\
\hline 8 & Local resources & & & \\
\hline 9 & Permanent resources & & & \\
\hline 10 & Usable by simple technologies & & \\
\hline
\end{tabular}

III. Uses of renewable energy

\begin{tabular}{|l|l|l|l|l|}
\hline 11 & Military uses & & & \\
\hline 12 & Domestic uses & & & \\
\hline 13 & Agricultural uses & & & \\
\hline 14 & Industrial uses & & & \\
\hline
\end{tabular}

IV. Obstacles to employing renewable energy

\begin{tabular}{|l|l|l|l|l|}
\hline 15 & Technological obstacles & & & \\
\hline 16 & Financial and economic obstacles & & & \\
\hline 17 & Environmental and climate obstacles & & & \\
\hline 18 & Awareness obstacles & & & \\
\hline
\end{tabular}

V. Potentials of renewable energy in KSA

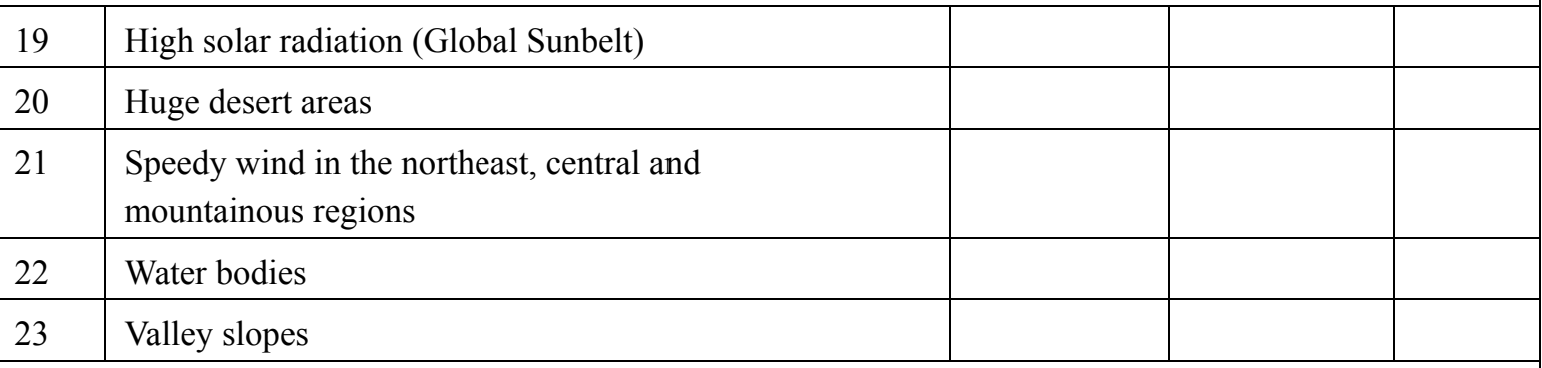

\section{The state efforts to employ renewable energy}

\begin{tabular}{|l|l|l|l|l|}
\hline 24 & King Abdulaziz City for Science and Technology & & & \\
\hline 25 & The Solar Village in Al-'Uyaynah & & & \\
\hline 26 & King Abdullah City for Atomic and Renewable Energy & & & \\
\hline 27 & National Development Strategy and Saudi Vision 2030 & & & \\
\hline 28 & The Renewable Energy Project Development Office & & & \\
\hline 29 & Sakaka solar project & & & \\
\hline 30 & Dumat Al Jandal Wind Farm & & & \\
\hline
\end{tabular}

\section{Copyright Disclaimer}

Copyright for this article is retained by the author(s), with first publication rights granted to the journal.

This is an open-access article distributed under the terms and conditions of the Creative Commons Attribution license (http://creativecommons.org/licenses/by/3.0/). 